\title{
The Study of Magnesium Substitution Effect on Physicochemical Properties of Hydroxyapatite
}

\author{
Liga Stipniece ${ }^{1}$, Kristine Salma-Ancane ${ }^{2}$, Dmitrijs Jakovlevs ${ }^{3}$, Natalija Borodajenko ${ }^{4}$, Liga Berzina-Cimdina ${ }^{5}$ \\ ${ }^{1-5}$ Riga Technical University
}

\begin{abstract}
In the present study, pure and Mg-substituted hydroxyapatite powders made up of needle-like and plate-like particles, respectively, have been synthesized by wet chemical precipitation of $\mathrm{CaO}, \mathrm{MgO}$ and $\mathrm{H}_{3} \mathrm{PO}_{4}$. The influence of different amounts of $\mathrm{MgO}$ addition into synthesis media on properties of as-synthesized and sintered powders has been evaluated.

Through the phase and chemical composition analysis it has been determined that the prepared powders contain various amounts of $\mathrm{Mg}$ (in the range between $0.21-4.72 \mathrm{wt} \%$ ). The substitution of $\mathrm{Mg}$ promoted the decomposition of hydroxyapatite to $\beta$-tricalcium phosphate.
\end{abstract}

Keywords: bioceramics, hydroxyapatite, magnesium, wet chemical precipitation

\section{INTRODUCTION}

Hydroxyapatite (HAp, chemical formula $\mathrm{Ca}_{10}\left(\mathrm{PO}_{4}\right)_{6}(\mathrm{OH})_{2}$ ) has attracted the attention of researchers over the past thirty years as an implant material because of its excellent biocompability and bioactivity. It is commonly the material of choice for the fabrication of dense and porous bioceramics [1]. All properties of HAp, including bioactivity, biocompatibility and solubility can be tailored within a wide range by controlling qualitatively and quantitatively ions substituted for $\mathrm{Ca}^{2+}, \mathrm{PO}_{4}^{3-}$ and $\mathrm{OH}^{-}$in the HAp lattice structure [2].

Magnesium ( $\mathrm{Mg}$ ) is known as one of the cationic substitutes for calcium (Ca) in the HAp lattice structure [3]. Magnesiumsubstituted HAp (Mg-HAp) can be expressed by a simplified chemical formula: $\mathrm{Ca}_{10-\mathrm{x}} \mathrm{Mg}_{\mathrm{x}}\left(\mathrm{PO}_{4}\right)_{6}(\mathrm{OH})_{2}$. $\mathrm{Mg}$ is also one of the predominant substitutes for $\mathrm{Ca}$ in biological apatite (enamel, dentin, and bone contain $0.44 \mathrm{wt} \%, 1.23 \mathrm{wt} \%$ and $0.72 \mathrm{wt} \%$ of $\mathrm{Mg}$, respectively) [3-7]. Accordingly, Mg-HAp materials are expected to have excellent biocompability and properties that can be favourably compared to those of hard tissues [7]. Caccioti et al. and Kim et al. have found through their studies that the presence of $\mathrm{Mg}$ ions within HAp lattice affects its crystallization in solution, its thermal stability, promotes the formation of $\beta$-tricalcium phosphate $(\beta-\mathrm{TCP})$ during thermal treatment, thus forming biphasic calcium phosphates (BCP) [5,8]. According to the literature, the replacement of $\mathrm{Ca}$ by $\mathrm{Mg}$ in HAp is limited. This is related to the size differences between $\mathrm{Mg}^{2+}$ and $\mathrm{Ca}^{2+}(\sim 0.28 \AA$ difference in radius according to the Pauling scale) [9]. The maximal amount of $\mathrm{Mg}$ substituting for $\mathrm{Ca}$ varies in previous research reports. For example, Mayer et al. [10] precipitated HAp containing up to $1.5 \mathrm{wt} \%$ of Mg. Fadeev et al. [11] reported that $\sim 10 \mathrm{wt} \%$ was the maximal amount of $\mathrm{Mg}$ ions that could be successfully incorporated into HAp structure replacing Ca ions. Riman et al. [12] even reported stable, phase-pure $\mathrm{Mg}$-substituted crystalline HAp containing from $\sim 2.0$ to $\sim 29 \mathrm{wt} \% \mathrm{Mg}$ obtained through the mechanochemicalhydrothermal technique, wherein at least $75 \mathrm{wt} \%$ of $\mathrm{Mg}$ substituted for $\mathrm{Ca}$ ions in the HAp lattice structure. The changes of crystal structure have a direct impact on the properties of Mg-HAp, compared to their non-substituted analogues [3,11]. Increasing concentration of $\mathrm{Mg}$ in HAp has the following effects on its properties: a) gradual decrease in crystallinity; b) increase in $\mathrm{HPO}_{4}$ incorporation, and c) increase in the extent of dissolution [13]. $\mathrm{Mg}$ is associated with mineralization of calcified tissues and indirectly influences mineral metabolism [6]. It becomes possible to tailor the physicochemical properties of HAp, as well as its biocompability and bioactivity, by controlling the $\mathrm{Mg}$ substitution of the HAp lattice structure [14].

The purpose of the present research has been to study the effect of partial $\mathrm{Mg}$ substitution for $\mathrm{Ca}$ on the structure and properties of HAp synthesized through wet chemical precipitation involving calcium oxide $(\mathrm{CaO})$, magnesia $(\mathrm{MgO})$ and orthophosphoric acid $\left(\mathrm{H}_{3} \mathrm{PO}_{4}\right)$ precursors.

\section{MATERIALS AND METHODS}

Pure and Mg-HAp powders containing various contents of $\mathrm{Mg}$ were synthesized from $\mathrm{CaO}$ (Riedel-de-Haën ${ }^{\circledR}$ ), $\mathrm{MgO}$ (ES/Scharlau) and $\mathrm{H}_{3} \mathrm{PO}_{4}$ (Sigma-Aldrich) through wet chemical precipitation, according to the scheme shown in Fig.1.

The starting slurries were obtained through "lime slaking" processes by dissolving $\mathrm{CaO}$ or $\mathrm{CaO} / \mathrm{MgO}$ powders (to obtain pure or $\mathrm{Mg}$ substituted products, respectively) into deionized $\mathrm{H}_{2} \mathrm{O}$, and completely homogenized by a planetary ball milling (FRITCH planetary mill PULVERISETTE 5) at $300 \mathrm{rpm}$ for 40 min. $\mathrm{MgO}$ contents in synthesis media ranged between $0.1-$ $20.0 \mathrm{wt} \%$ in respect to the total amount of mixture containing $\mathrm{CaO}$ and $\mathrm{MgO}$.

Precipitation reaction was carried out in a laboratory reactor (IKA EUROSTAR Power Control-Visc P7), where an aqueous solution of $2.0 \quad \mathrm{M} \mathrm{H}_{3} \mathrm{PO}_{4}$ was added to $\mathrm{Ca}(\mathrm{OH})_{2}$ or $\mathrm{Mg}(\mathrm{OH})_{2} / \mathrm{Ca}(\mathrm{OH})_{2}$ suspension at a slow addition rate $(\sim 0.75$ $\mathrm{ml} / \mathrm{min}$ ) using titration equipment (TITRONIC) under vigorous stirring. The temperature of synthesis media was maintained constant $\left(45^{\circ} \mathrm{C}\right)$ and the $\mathrm{pH}$ was continuously monitored and adjusted to 9.0 during synthesis by adding $2.0 \mathrm{M} \mathrm{H}_{3} \mathrm{PO}_{4}$, and stabilized for $1 \mathrm{~h}$.

After synthesis the precipitates were aged in mother liquor for $\sim 20 \mathrm{~h}$ at ambient temperature, filtered and dried at $105^{\circ} \mathrm{C}$ 
for $\sim 20 \mathrm{~h}$. The powders were ground and analysed (assynthesized powders). Subsequent sintering of as-synthesized powders followed in an electrically heated furnace (Nabertherm LHT 08/17) in air atmosphere at $1100{ }^{\circ} \mathrm{C}$ (sintered powders).

Comprehensive characterization techniques, including Fourier transform infrared spectrometer (FT-IR) - Varian 800, $P A N a l i t i c a l$ X'pert PRO X-ray powder diffractometer (XRD), differential thermal analyzer (DTA) B̈̈HR DTA703, heating microscope (HM) Hesse Instruments Heating Microscope EM 201 (HT-16 (1600/80)), and field emission scanning electron microscopy (FE-SEM) Tescan Mira/LMU and energy dispersive X-ray spectroscopy (FE-SEM/EDS) (Inca Energy 350), were used to investigate the effect of $\mathrm{Mg}$ substitution on phase composition, crystallinity, thermal stability, sintering behaviour, morphology, microstructure and chemical composition, respectively, of as-synthesized and sintered products.

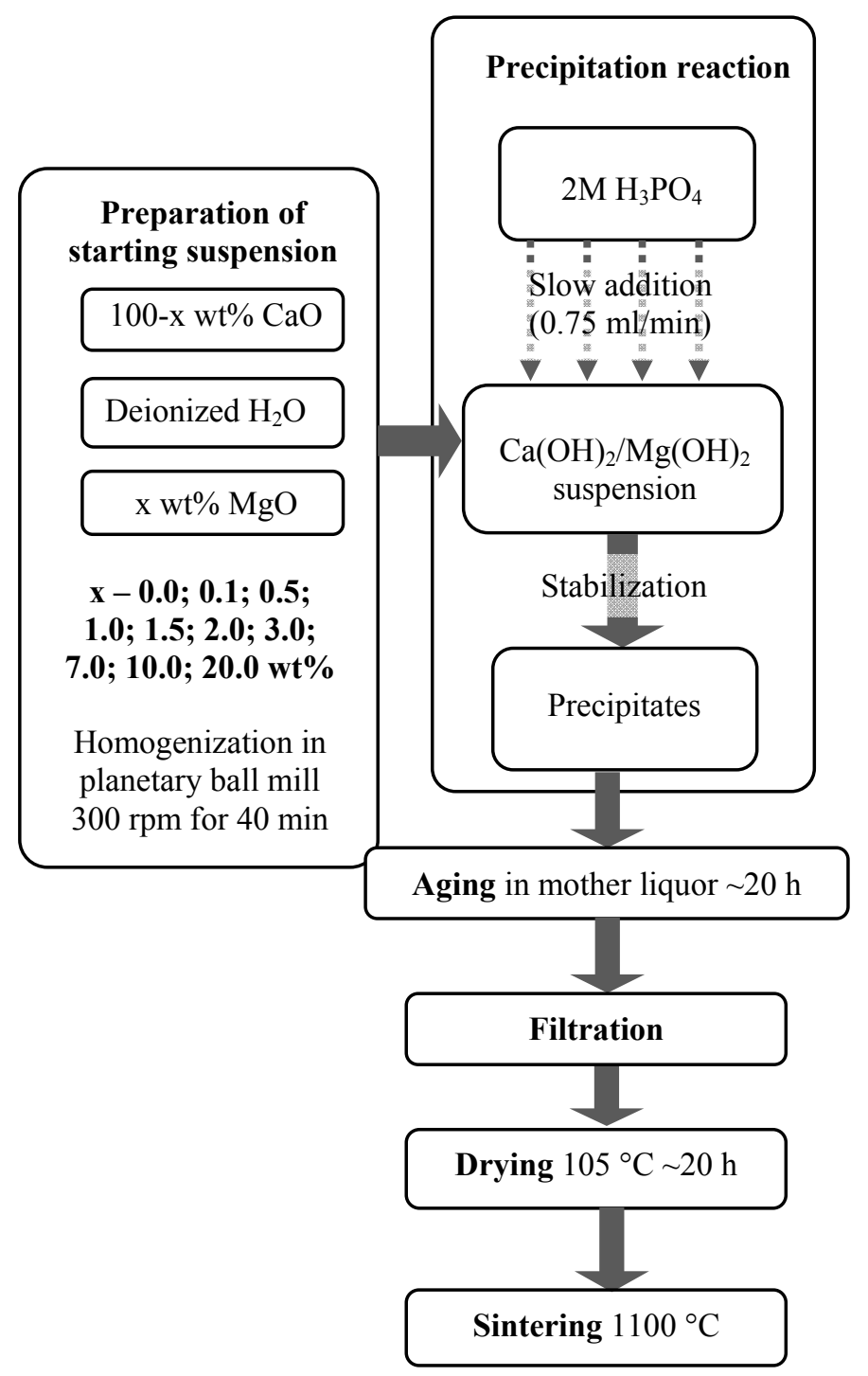

Fig. 1. Technological scheme of preparation of HAp and Mg-HAp powders
The mean sizes of crystallites of as-synthesized HAp and Mg-HAp products were calculated according to the Scherrer's equation:

$$
D=k \cdot \lambda /(F W H M \cdot \cos \theta)
$$

In order to calculate the mean sizes of crystallites of assynthesized powders, the peak of XRD patterns of assynthesized product was chosen at $25.9^{\circ} 2 \theta$, since it was isolated, i.e., did not overlap with other diffraction peaks. In the case of sintered powders, to calculate the mean sizes of crystallites the peaks of XRD patterns of sintered product were chosen at $25.9^{\circ} 2 \theta$ and $32.9^{\circ} 2 \theta$, the FWHM values of which represented length and width of crystallites, respectively [15].

\section{RESULTS AND DISCUSSION}

\section{A. Chemical Composition}

FE-SEM/EDS measurements show the presence of $\mathrm{Ca}, \mathrm{P}$, $\mathrm{Mg}$ and $\mathrm{O}$ in both HAp and Mg-HAp samples. Powders prepared with $\mathrm{CaO}$ and $\mathrm{H}_{3} \mathrm{PO}_{4}$ without extra $\mathrm{MgO}$ addition in the starting suspension contain $0.21 \mathrm{wt} \%$ of $\mathrm{Mg}$. This $\mathrm{Mg}$ content results from impurities in commercial $\mathrm{CaO}$. In general, $\mathrm{Mg}$ content in synthesis products increased proportionally with the amount of $\mathrm{MgO}$ in the starting slurry between 0.21 and $4.72 \mathrm{wt} \%$ (see Table 1 and Fig. 2). It is likely to achieve concentrations of $\mathrm{Mg}$ substitutions (i.e., 0.52, 0.64 and 0.83 $w t \%)$ in HAp resembled to those of bone mineral by adding $1.5,2.0$ and $3.0 \mathrm{wt}^{\mathrm{O}} \%$ of $\mathrm{MgO}$, respectively, into synthesis media.

TABLE 1

Mg CONCENTRATION IN SyNTHESIS PRODUCTS SinTEREd AT $1100^{\circ} \mathrm{C}$ FOR $1 \mathrm{H}$ DETERMINED BY FE-SEM/EDS ANALYSIS

\begin{tabular}{|l|l|}
\hline Sample & Mg concentration, wt\% \\
\hline HAp & $0.21 \pm 0.03$ \\
\hline 0.1_Mg-HAp & $0.21 \pm 0.06$ \\
\hline 0.5_Mg-HAp & $0.31 \pm 0.09$ \\
\hline 1.0_Mg-HAp & $0.43 \pm 0.10$ \\
\hline 1.5_Mg-HAp & $0.52 \pm 0.29$ \\
\hline 2.0_Mg-HAp & $0.64 \pm 0.08$ \\
\hline 3.0_Mg-HAp & $0.83 \pm 0.21$ \\
\hline 7.0_Mg-HAp & $1.50 \pm 0.45$ \\
\hline 10.0_Mg-HAp & $2.11 \pm 0.15$ \\
\hline 20.0_Mg-HAp & $4.72 \pm 1.24$ \\
\hline
\end{tabular}




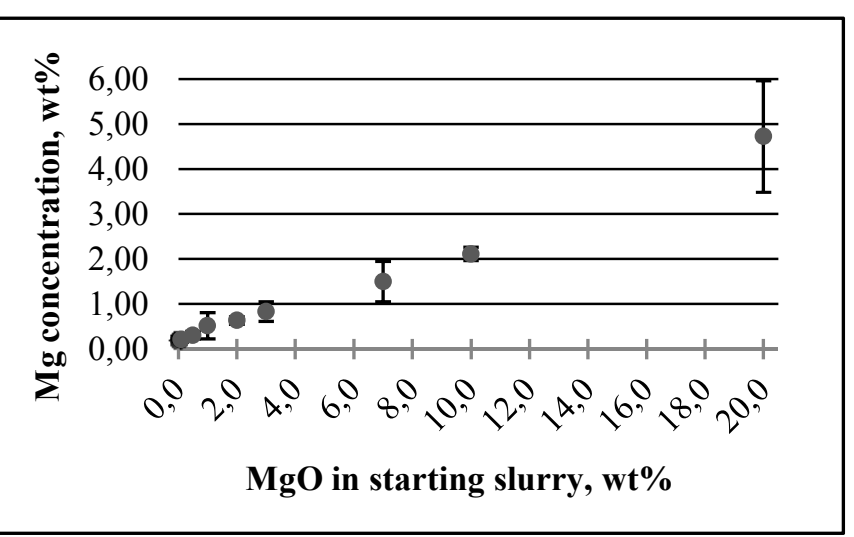

Fig. 2. Mg concentration in HAp and Mg-HAp powders $(0.1 ; 0.5,1.0 ; 1.5$, $2.0,3.0 ; 7.0,10.0,20.0 \mathrm{wt} \% \mathrm{MgO})$ sintered at $1100{ }^{\circ} \mathrm{C}$ for $1 \mathrm{~h}$ determined by FE-SEM/EDS analysis

\section{B. Phase Composition, Cristallinity}

XRD patterns of as-synthesized HAp and Mg-HAp powders are compared in Fig. 3. Identification of the crystalline phases was carried out using the X-ray diffraction data of existing clean phases from the American Mineralogist Crystal Structure Database (AMCDS). All the as-synthesized powders had a low degree of crystallinity as evidenced by XRD patterns with relatively broad and low intensity XRD peaks, which were attributed to small crystallite size characteristic of the apatite phase. No observable differences of crystallinity in XRD patterns of as-synthesized HAp and Mg-HAp were detected. It was observed that in our case incorporation of $\mathrm{Mg}$ into HAp had only a minor influence on the crystal dimensions of as-synthesized HAp and Mg-HAp. Thus, it can be concluded that $\mathrm{Mg}$ ions recruited to $\mathrm{HAp}$ structure cause insignificant deformations of crystallites. It was evident by the absence of unreacted $\mathrm{MgO}$ ( $A M C D S$ $\# 0004683)$ or presence of $\mathrm{Mg}(\mathrm{OH})_{2}(A M C D S \# 0002434)$, and magnesium phosphates (MgP) that could be formed as byproducts of synthesis (i.e., newberyite $\left(\mathrm{MgHPO}_{4} * 3 \mathrm{H}_{2} \mathrm{O}\right.$; $A M C S D \quad \# 0009693)$, farringtonite $\left(\mathrm{Mg}_{3}\left(\mathrm{PO}_{4}\right)_{2} ; A M C D S\right.$
$\# 0011901)$, bobierrite and baricite $\left(\mathrm{Mg}_{3}\left(\mathrm{PO}_{4}\right)_{2} * 8\left(\mathrm{H}_{2} \mathrm{O}\right)\right.$; AMCDS \#0001049)) in any of Mg-HAp patterns, where all $\mathrm{Mg}$ was incorporated into $\mathrm{Mg}-\mathrm{HAp}$.

After sintering at $1100{ }^{\circ} \mathrm{C}$ for $1 \mathrm{~h}$ the obtained XRD patterns of HAp and Mg-HAp are reported in Fig. 4 and Fig. 5. The XRD analyses show that products with low concentrations of Mg, i.e., HAp, 0.1_Mg-HAp, 0.5_Mg-HAp, 1.0_Mg-HAp, 1.5_Mg-HAp and 2.0_Mg-HAp, contain a single crystalline phase - HAp (AMCDS \#0001257) (see Fig. 4). When concentration of $\mathrm{Mg}$ in synthesis products increased (between $0.83-4.72 \mathrm{wt} \%$ ), characteristic peaks of HAp and $\beta$ TCP appeared in captured powder X-ray diffraction patterns suggestive of existence of $\beta$-TCP and/or whitlockite $(\mathrm{Mg}-\beta$ TCP, Mg-substituted $\beta$-TCP) in these samples (see Fig. 5). To identify phases $2 \theta$ the values reported in AMCSD \#0004624 and AMCSD \#0013351 for synthetic $\beta$-tricalcium phosphate and whitlockite were used, respectively.

Incorporation of $\mathrm{Mg}$ led to a gradual transformation of HAp in whitlockite depending on $\mathrm{Mg}$ content, which was also confirmed by the DTA and HM data.

\section{Molecular Composition}

The FT-IR spectra of as-synthesized HAp and Mg-HAp present the characteristic vibrational bands of typical partially carbonated and hydrated apatite. FT-IR spectra of sintered samples differ significantly from the FT-IR spectra of as-synthesized samples. All spectra have intensive characteristic bands of HAp originating from vibration of phosphates groups $\left[\mathrm{PO}_{4}\right]$ and bands corresponding to stretching and vibrational modes of the hydroxyl groups [OH]. Thus, increase in $\mathrm{Mg}$ content of sintered samples observed $\left[\mathrm{PO}_{4}\right]$ characteristic absorption band broadening and splitting. In the case of 7.0_Mg-Hap, 10.0_Mg-HAp and 20.0_Mg-HAp extra peaks were detected. These bands can be ascribed to the $\left[\mathrm{PO}_{4}\right]$ group vibration modes characteristic of whitlockite. By increasing content of $\mathrm{Mg}$ in HAp structure, extra peaks become more intense (see Fig. 6).

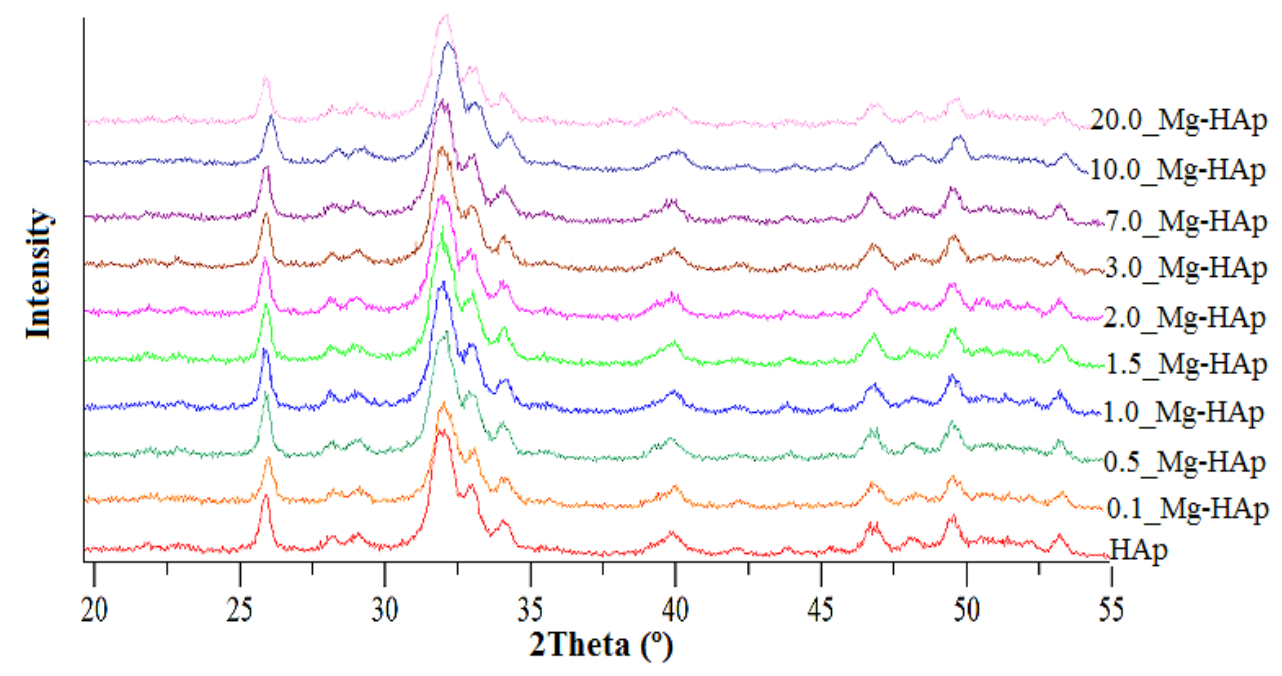

Fig. 3. XRD patterns of as-synthesized HAp and Mg-HAp powders dried at $105^{\circ} \mathrm{C}$ for $20 \mathrm{~h}$ 


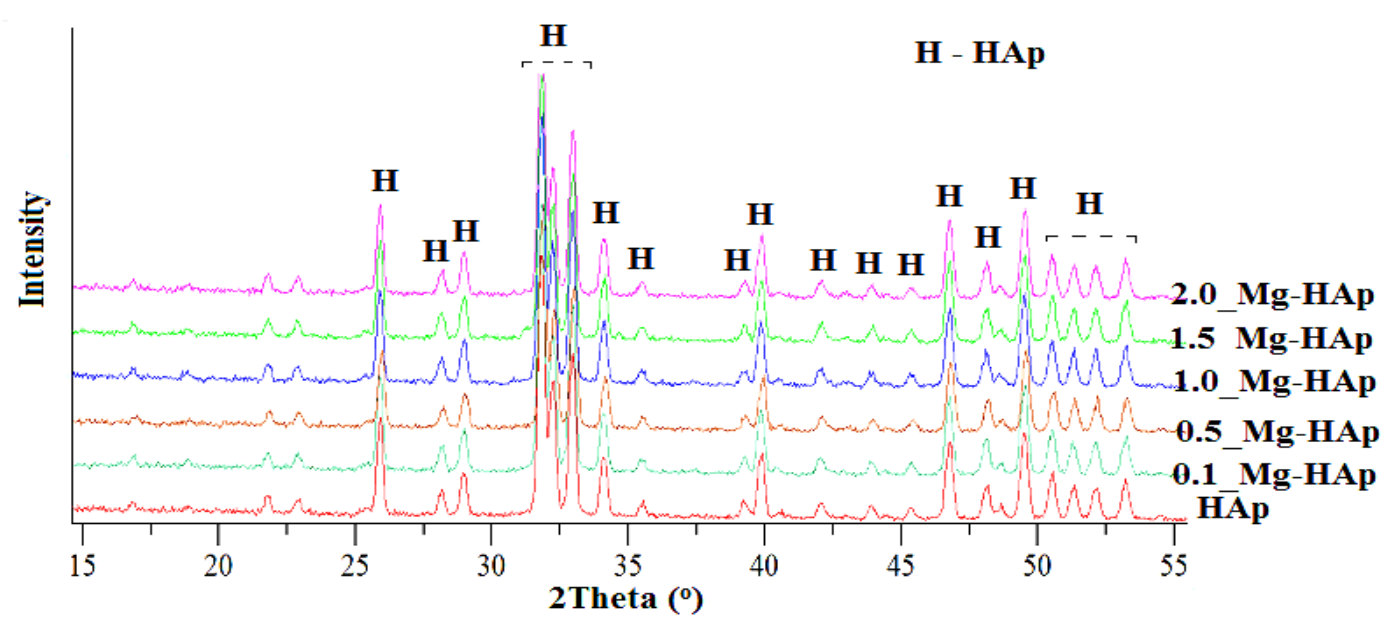

Fig. 4. XRD patterns of sintered HAp and Mg-HAp (HAp, 0.1_Mg-HAp, 0.5_Mg-HAp, 1.0_Mg-HAp, 1.5_Mg-HAp, 2.0_Mg-HAp) powders at $1100{ }^{\circ} \mathrm{C}$ for $1 \mathrm{~h}$

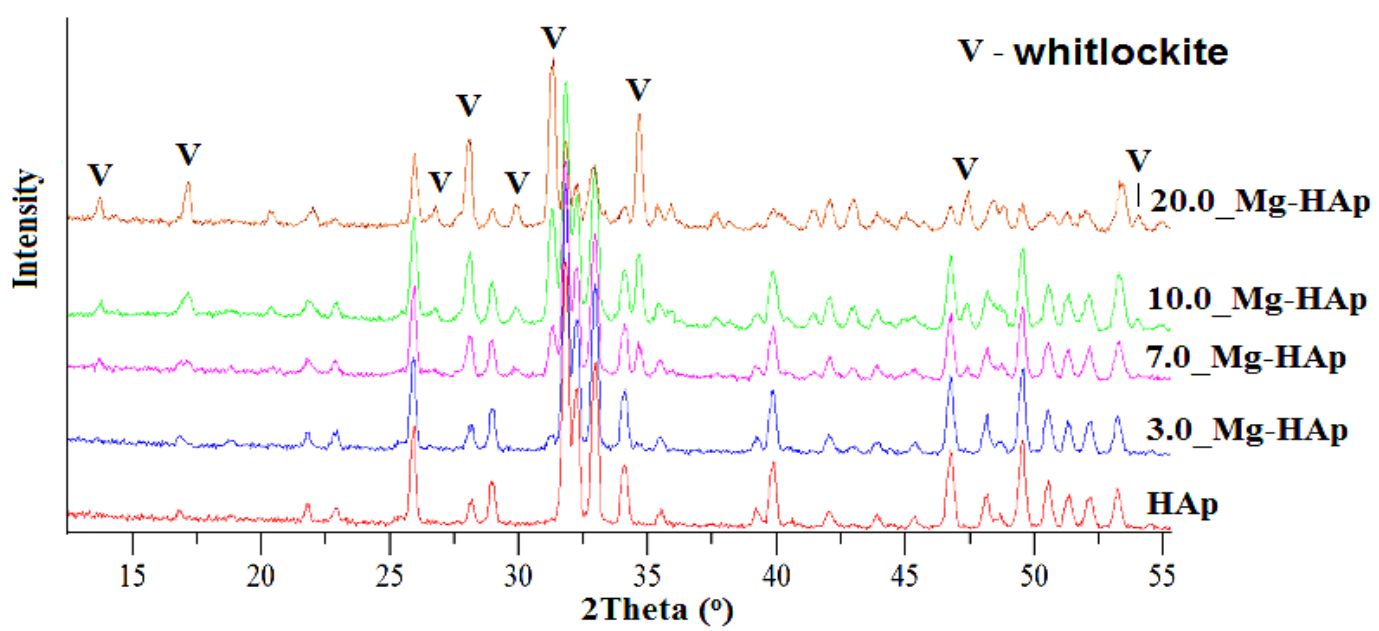

Fig. 5. XRD patterns of sintered Mg-HAp (3.0_Mg-HAp, 7.0_Mg-HAp, 10.0_Mg-HAp, 20.0_Mg-HAp) powders at $1100{ }^{\circ} \mathrm{C}$ for $1 \mathrm{~h}$

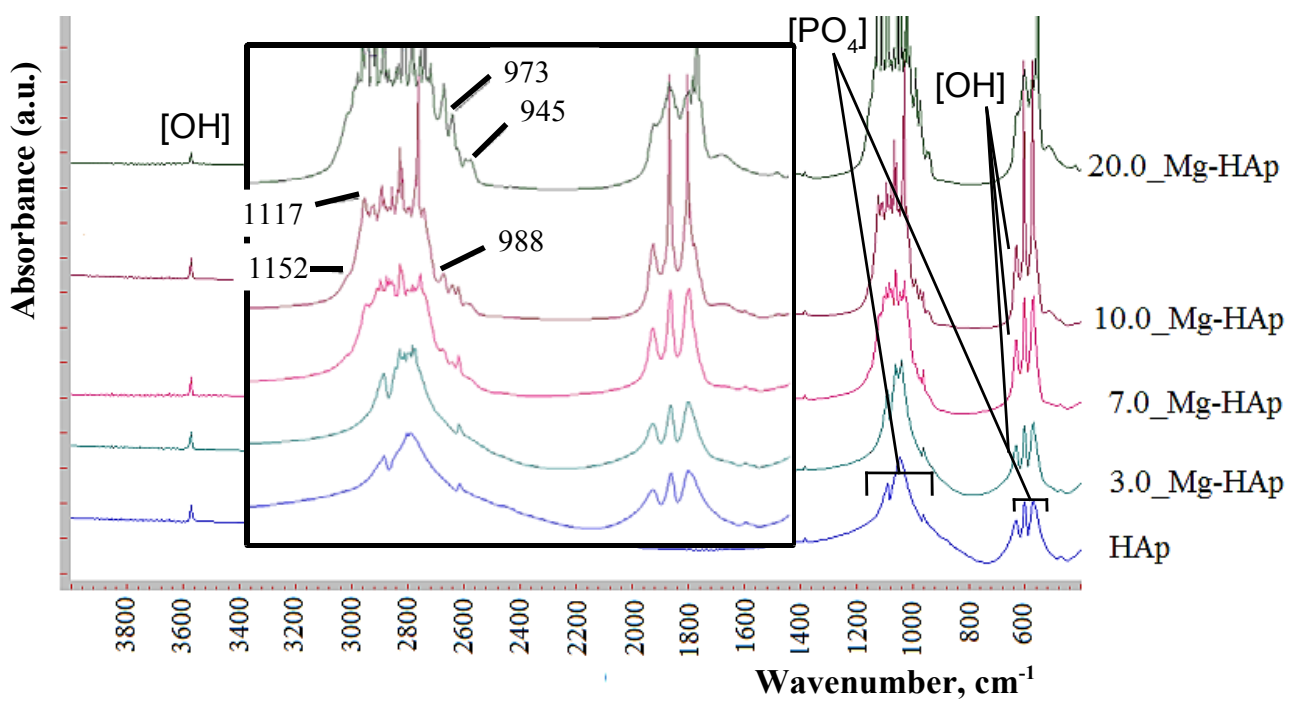

Fig. 6. FT-IR spectra of sintered HAp and Mg-HAp powders at $1100^{\circ} \mathrm{C}$ for $1 \mathrm{~h}[16]$ 


\section{Thermal Stability and Sintering Behaviour}

DTA analysis (Fig. 7) up to $1400{ }^{\circ} \mathrm{C}$ of HAp and 10_MgHAp powders confirmed the results of XRD analyses. Endothermic effect in the temperature region from $50-150{ }^{\circ} \mathrm{C}$ was due to the removal of physically adsorbed $\mathrm{H}_{2} \mathrm{O}$ and $\mathrm{CO}_{2}$. Pure HAp did not show any other endothermic peaks up to $1400{ }^{\circ} \mathrm{C}$. In the case of 10.0_Mg-HAp, the DTA curve showed some distortions in the temperature region from 700 to 1150 ${ }^{\circ} \mathrm{C}$. Thus, this region of DTA curve could be caused due to the decomposition of the Mg-HAp to whitlockite phase. This effect was also observed in the studies of HM (Fig. 8).

The sintering process of Mg-HAp bioceramics started at temperature $\sim 680-750{ }^{\circ} \mathrm{C}$. Linear shrinkage at the temperature range of $650-1000{ }^{\circ} \mathrm{C}$ pointed to the beginning of phase decomposition; this process overlapped with the beginning of compaction of bioceramics.

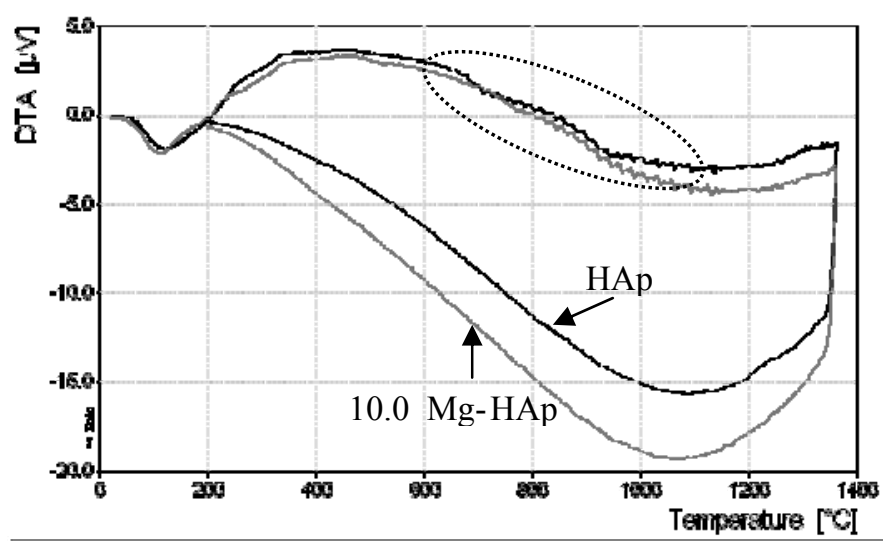

Fig. 7. DTA curves of HAp and 10.0_Mg-HAp products

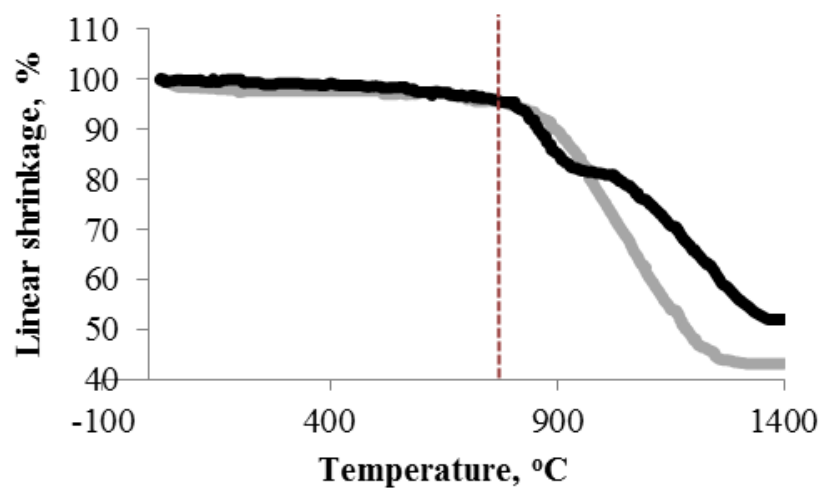

$\longrightarrow$ HAp $\longrightarrow$ 10.0_Mg-HAp

Fig. 8. Thermal shrinkage of HAp and 10.0_Mg-HAp samples

\section{E. Morphology and Microstructure}

The samples were collected in the form of suspension after the stabilization period of $\sim 1 \mathrm{~h}$ to investigate the morphology of as-synthesized HAp and Mg-HAp powders. FE-SEM microphotograph (Fig. 9) of as-synthesized pure HAp shows typical nanosized needle-like crystallite morphology with homogenous, thin, elongated $(\sim 150-200 \mathrm{~nm})$ crystallites.
Morphologies of as-synthesized Mg-HAp suspensions show different shapes and sizes of crystallites. Mg-HAp suspensions after synthesis show the plate-like crystallite agglomerate morphology. As $\mathrm{Mg}$ content in the synthesis products increased (especially in the case of samples 10.0_Mg-HAp and 20.0_Mg-HAp), crystallites become thinner and finer and more agglomerated. Since crystallites of as-synthesized HAp and Mg-HAp tend to agglomerate, it is impossible to determine the crystallite sizes through the analysis of the FESEM images, because it is possible to distinguish only primary agglomerates of crystallites.

However, calculations using the Scherrer's equation showed that the mean sizes of crystallites of as-synthesized HAp and Mg-HAp were in the range between $20-25 \mathrm{~nm}$.

The similar values of mean sizes of crystallites for assynthesized powders containing different amounts of $\mathrm{Mg}$ imply that in our case the incorporation of $\mathrm{Mg}$ ions probably had only a minor influence on crystal dimensions.
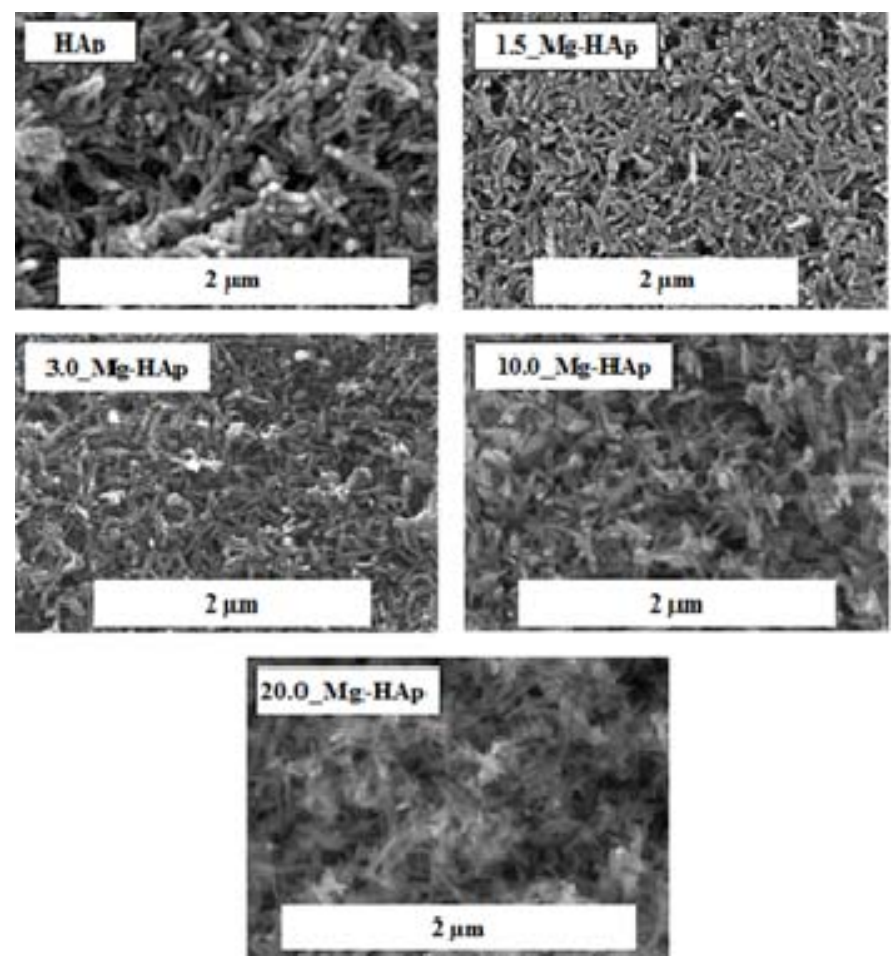

Fig. 9. FE-SEM microphotographs of as-synthesized powder suspensions dried at $105^{\circ} \mathrm{C}$ for $20 \mathrm{~h}$

The results of FE-SEM investigation of the microstructure of sintered pure and Mg-HAp bioceramics showed that the incorporation of $\mathrm{Mg}$ into HAp structure increased the densification of HAp bioceramics. It is evident that an increase in $\mathrm{Mg}$ content in bioceramic samples induces the formation of elongate grains. After the thermal treatment, the calculated values of length and width of crystallites of HAp and Mg-HAp products were $\sim 30-40 \mathrm{~nm}$, thus, indicating that the sintering at $1100{ }^{\circ} \mathrm{C}$ for $1 \mathrm{~h}$ induced the rounding and compression of crystallites, being a characteristic of HAp sintering process. It was observed that in the case of 7.0_MgHAp and 20.0_Mg-Hap, the microstructure was more microporous than that of other $\mathrm{Mg}$-substituted bioceramic 
structures due to the presence of the secondary phase whitlockite (Fig. 10).

All pure-phase Mg-HAp bioceramics showed good densification with respect to HAp. Porosity and bulk density of HAp and Mg-HAp bioceramics after thermal treatment were also determined using a method based on Archimedes' principle, and the results confirm FE-SEM microphotographs (Fig. 11).
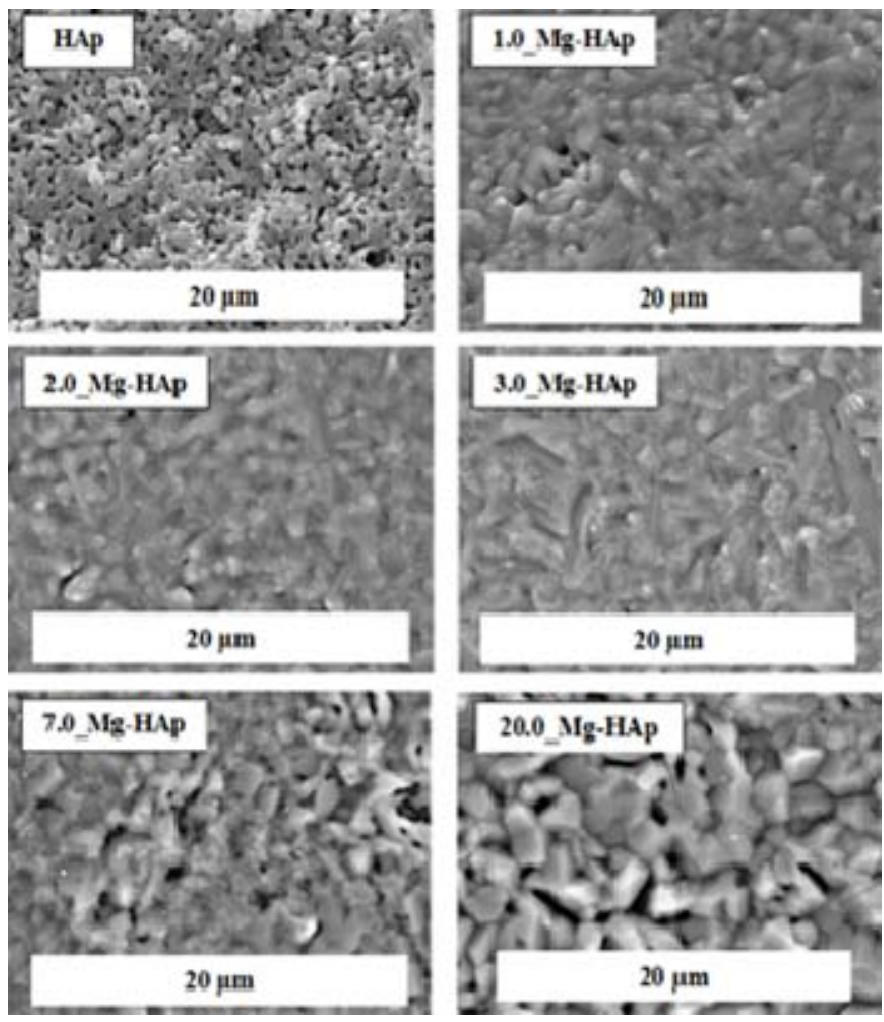

Fig. 10. FE-SEM microphotographs of surface microstructures of $\mathrm{HAp}, \mathrm{Mg}$ HAp bioceramics sintered at $1100{ }^{\circ} \mathrm{C}$ for $1 \mathrm{~h}$

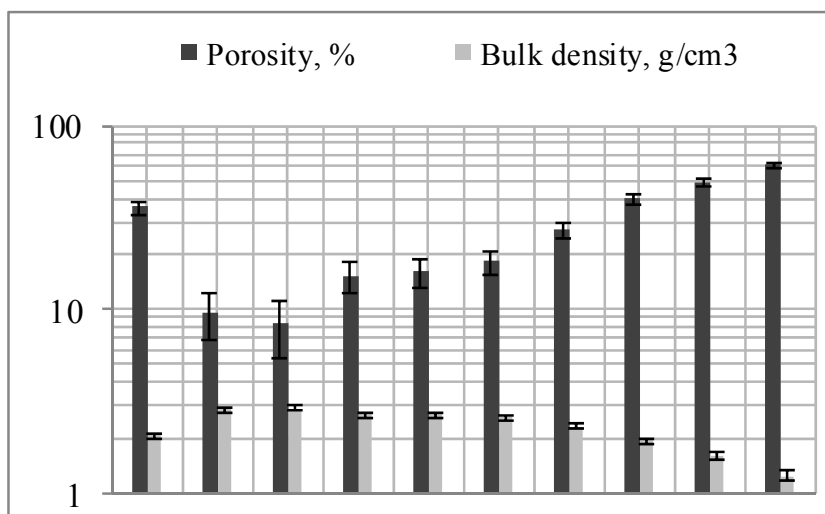

$\begin{array}{lllllllllll}0.0 & 0.1 & 0.5 & 1.0 & 1.5 & 2.0 & 3.0 & 7.0 & 10.0 & 20.0\end{array}$

MgO content in starting slurry, wt $\%$

Fig. 11. HAp $\left(0.0 \quad w_{t} \% \quad \mathrm{MgO}\right)$ and $\mathrm{Mg}-\mathrm{HAp} \quad(0.1-20.0 \quad \mathrm{wt} \% \mathrm{MgO})$ bioceramics total porosity and bulk density

\section{CONCLUSIONS}

Mg-substituted hydroxyapatite with variable amount of $\mathrm{Mg}$ (0.21-4.72 wt \%) incorporated into the structure has been synthesized by modified wet chemical precipitation. After the synthesis and thermal treatment, the obtained X-ray diffraction analysis has not shown the presence of $\mathrm{Mg}(\mathrm{OH})_{2}$ and $\mathrm{MgO}$ in $\mathrm{Mg}$-substituted hydroxyapatite products, which indicates complete $\mathrm{Mg}$ ion incorporation into the hydroxyapatite structure. $\mathrm{Mg}$ concentration of $\mathrm{Mg}$-substituted hydroxyapatite products increases with an increase in the $\mathrm{MgO}$ content in $\mathrm{Ca}(\mathrm{OH})_{2} / \mathrm{Mg}(\mathrm{OH})_{2}$ suspension. Mg-substituted hydroxyapatite thermal stability decreases by increasing the content of $\mathrm{Mg}$ into hydroxyapatite products; Mg-substituted hydroxyapatite partial transformation to $\mathrm{Mg}$-substituted $\beta$-tricalcium phosphate or whitlockite occurred. The incorporation of $\mathrm{Mg}$ into hydroxyapatite structure significantly affects its crystallite morphology and microstructure of bioceramics.

\section{ACKNOWLEDGEMENTS}

The research has been supported by the Latvian State Research Programme "Development of Innovative Multifunctional Materials, Signal Processing and Information Technology for Competitive Science-intensive Products" within the framework of project No. 4 "New Materials and Technologies for Evaluating Biological Tissue, and Replace".

\section{REFERENCES}

1. Albrektsson, T., Johansson, C., Osteoinduction, osteoconduction and osseointegration. Eur. Spine J., 2001, vol. 10, p. S96-S101. http://dx.doi.org/10.1007/s005860100282

2. Boanini, E., Gazzano, M., Bigi, A., Ionic substitutions in calcium phosphates synthesized at low temperature, Acta Biomaterialia, 2010, vol. 6, p. 1882.-1894.

3. Landi, E., Logroscino, G., Proietti, L., Tampieri, A., Sandri, M., Sprio, S., Biomimetic Mg-substituted hydroxyapatite: from synthesis to in vivo behavior. J. Mater. Sci.: Mater. Med., 2008, vol. 19, pp. 239-247. http://dx.doi.org/10.1007/s10856-006-0032-y

4. Matsunga, K., First-principles study of substitutional magnesium and zinc in hydroxyapatite and octacalcium phosphate. The Journal of Chemical Physics, 2008, vol. 128.

5. Cacciotti, I., Bianco, A., Lombardi, M., Montanaro, L., Mg-substituted hydroxyapatite nanopowders: Synthesis, thermal stability and sintering behavior. J. Eur. Ceram. Soc., 2009, vol. 29, p. 2969-2978. http://dx.doi.org/10.1016/j.jeurceramsoc.2009.04.038

6. Tardei, C., Grigore, F., Pasuk, I., Storleriu, S., The study of $\mathrm{Mg}^{2+} / \mathrm{Ca}^{2+}$ substitution of $\beta$-tricalcium phosphate. Journal of Optoelectronics and advanced Materials, 2006, vol. 8, p. 568-571.

7. Ren, F., Leng, Y., Xin, R., Ge, X., Synthesis, characterization and ab intio simulation of magnesium-substituted hydroxyapatite. Acta Biomater. 2010, vol. 6, p. 2787-2796. http://dx.doi.org/10.1016/j.actbio.2009.12.044

8. Kim, S.R., Lee, J.H., Kim, Y.T., Riu, D.H., Jung, S.J., Lee, Y.J., Chung, S.C., Kim, Y.H., Synthesis of Si, Mg substituted hydroxyapatites and their sintering behaviour. Biomaterials, 2003, vol. 24, p. 1389-1398. http://dx.doi.org/10.1016/S0142-9612(02)00523-9

9. Laurencin, D., Barrios, N.A., de Leeuw, N.H., Gervais, C., Bonhommec, C., Mauri, F., Chrzanowski, W., Knowles, J.C., Newport, R.J, Wong, A., Gan, Z., Smith, M.E., Magnesium incorporation into hydroxyapatite. Biomaterials, 2011, vol.32, p. 18261837. http://dx.doi.org/10.1016/j.biomaterials.2010.11.017

10. Mayer, I, Schlam, R, Featherstone, J.D.B., Magnesium-containing carbonate apatites. Journal of Inorganic Biochemistry, 1997, p. 1-6. http://dx.doi.org/10.1016/S0162-0134(96)00145-6 
11. Fadeev, I.V., Shvorneva, L.I., Barinov, S.M., Orlovskii, V.P. Synthesis and structure of magnesium-substituted hydroxyapatite, Inorg. Mater., 2003, vol. 39, p. 947-950.

12. Riman, R.E., Suchanek, W., Shuk, P., TenHuisen, K.S., Magnesiumsubstituted hydroxyapatites. US Patent 6921544 B2 (2005).

13. Suchanek, W.L., Byrappa, K., Shuk, P., Riman, R.E., Janas, V.F. TenHuisen, K.S., Preparation of magnesium-substituted hydroxyapatite powders by the mechanochemical-hydrothermal method. Biomaterials, 2004, vol. $25, \quad$ p. $\quad 4647-4657$. http://dx.doi.org/10.1016/j.biomaterials.2003.12.008

14. Landi, E., Tampieri, A., Mattioli-Belmonte, M., Celotti, G., Sandri, M., Gigante, A., Fava, P., Biagini, G., Biomimetic Mg- and Mg, COsubstituted hydroxyapatites: synthesis characterization and in vitro behavior. J. Eur. Ceram. Soc., 2006, vol. 26, p. 2593-2601. http://dx.doi.org/10.1016/j.jeurceramsoc.2005.06.040

15. Sanosh, K.P., Chu, M.-C., Balakrishan, A., Synthesis of nano hydroxyapatite powder that simulate teeth particle morphology and composition. Curr. Appl. Phys., 2009, vol. 9, p. 1459-1462 http://dx.doi.org/10.1016/j.cap.2009.03.024

16. Pena, J., Vallet-Regi, M., Hydroxyapatite, tricalcium phosphate and biphasic materials prepared by a liquid mix technique. J. Eur. Ceram. Soc., 2003, vol. 23, p. $1687-1696$. http://dx.doi.org/10.1016/S0955-2219(02)00369-2

Liga Stipniece, Mg.sc.ing., Research Assistant at the Institute of General Chemical Engineering, Riga Technical University. Main fields of interest include the synthesis and characterization of substituted HAp and the studies of HAp structural stability.

E-mail: liga.stipniece@,rtu.lv

Kristine Salma-Ancane, Dr.sc.ing., Lecturer and Researcher at the Institute of General Chemical Engineering, the Faculty of Materials Science and Applied Chemistry, Riga Technical University. She is the author of more than 40 scientific publications in the branch of hydroxyapatite synthesis and characterization. Over the past 5 years, her scientific interest has been focused on the study of the influence of different technological parameters on physiochemical properties of hydroxyapatite bioceramics. E-mail: kristine.salma-ancane(@),rtu.lv

Dmitrijs Jakovlevs, Mg.sc.ing., Researcher at Rudolfs Cimdins Riga Biomaterials Innovation and Development Centre, Riga Technical University. $\mathrm{He}$ is a co-author of more than 20 scientific publications in the field of structural characterization of materials, such as biomaterials, clays, nanocomposites, $\mathrm{TiO}_{2}$ ceramics etc. using the field emission scanning electron microscopy.

E-mail: Dmitrijs.Jakovlevs@rtu.lv

Natalija Borodajenko, Mg.sc.ing., Researcher at the Institute of General Chemical Engineering of Riga Technical University. She is an operator of Fourier transform infrared spectrometer and a co-author of more than 30 scientific publications.

E-mail: natalija.borodajenko@rtu.1v

Liga Berzina-Cimdina, Dr.sc.ing., a Professor, the Head of the Institute of General Chemical Engineering, Director of Rudolfs Cimdins Riga Biomaterials Innovation and Development Centre, and the Head of the Department of General Chemical Engineering at RTU, the Faculty of Materials Science and Applied Chemistry. She manages study programme specializations for: Chemistry and Technology of Biomaterials, Environmental Engineering, General Chemical Technology. Scientific research activities of Prof. L.Berzina-Cimdina include the management of international and regional projects (the EU, the Balkan countries, Latvia), development of new biomaterials and eco-materials, research of new applications for these materials and research on the interaction of materials and biological systems. She is the author of more than 100 scientific publications, as well as the author and a co-author of 3 patents.

E-mail: liga.berzina-cimdina@rtu.lv

\section{Līga Stīpniece, Kristīne Šalma-Ancāne, Dmitrijs Jakoṿ̦evs, Natālija Borodajenko, Līga Bērziņa-Cimdiṇa. Pētījumi par magnija iekḷaušanās ietekmi uz hidroksilapatīta fizikālḳīmiskajām īpašībām}

Darba mērḳis bija iegūt hidroksilapatīta biokeramiku ar variējamu Mg saturu. Mērkạa sasniegšanai tika izvirzīti sekojoši uzdevumi - izstrādāt modificētu hidroksilapatīta sintēzes tehnoloǵiju $\mathrm{Mg}$ saturoša reaǵenta pievienošanai sintēzes vidē, kā arī $\left(\mathrm{Mg}^{2+}\right)$ jonu iekḷaušanai sintēzes produktu struktūrā un izvērtēt $\left(\mathrm{Mg}^{2+}\right)$ jonu iekḷaušanas efektivitāti un ietekmi uz hidroksilapatīta produktu îpašībām pēc sintēzes un termiskās apstrādes, veikt iegūto sintēžu produktu fāžu un molekulārā sastāva, kā arī morfoloǵijas, mikrostruktūras pētījumus pēc sintēzes un termiskās apstrādes, kā arī veikt sintēžu produktu ķīmisko elementu koncentrācijas analīzi un termiskās stabilitātes pētījumus. Tika sintezēts ar Mg aizvietots hidroksilapatīts ar variējamu (0.21-4.72 masas\%) Mg saturu, izmantojot modificētu šķ̄ìuma ķ̄imiskās nogulsnēšanas metodi no CaO, $\mathrm{MgO}$ un $\mathrm{H}_{3} \mathrm{PO}_{4}$. Pēc sintēzes un termiskās apstrādes ar $\mathrm{Mg}$ aizvietota hidroksilapatīta produktu rentgendifrakcijas ainās netiek detektētas tādas blakusfāzes kā $\mathrm{Mg}(\mathrm{OH})_{2}$ un $\mathrm{MgO}$, kas liecina par pilnīgu Mg jonu iekḷaušanos hidroksilapatīta struktūrā. Lauka emisijas skenējošās elektronu mikroskopijas/enerğijas dispersīvās rentgenstaru spektroskopijas dati liecina, ka Mg koncentrācija sintēžu produktos pieaug līdz ar MgO daudzumu palielināšanu izejas $\left(\mathrm{Ca}(\mathrm{OH})_{2} / \mathrm{Mg}(\mathrm{OH})_{2}\right)$ suspensijā. Pauugstinoties iekḷautā $\mathrm{Mg}$ daudzumam produktos, samazinās ar Mg aizvietota hidroksilapatīta termiskā stabilitāte, notiek dal̦ēja fāžu transformācija uz ar Mg aizvietotu $\beta$-trikalcija fosfātu jeb vitlokītu. Hidroksilapatīta struktūrā iekḷautais Mg būtiski izmaina to produktu kristalītu morfologiju un biokeramikas mikrostruktūru. Hidroksilapatîtam raksturīga adatveida kristalītu aglomerātu morfologija, savukārt ar Mg aizvietotam hidroksilapatītam - plākšņveida kristalītu aglomerātu morfologija.

Лига Стипниеце, Кристине Салма-Анцане, Дмитрий Яковлев, Наталия Бородаенко, Лига Берзиня-Цимдиня. Изучение физико-химических свойств магний-замещенного гидроксиапатита

Целью работы было получение биокерамики гидроксиапатита с переменным содержанием Мg. Для достижения этой цели были определены задачи - разработать технологии синтеза $\mathrm{Mg}$-замещенного гидроксиапатита, оценить эффективность ионного включения в структуре гидроксиапатита и оценить их влияние на характеристики продуктов гидроксиапатита, изучить фазовый и молекулярный состав продуктов синтеза, а также изучить морфологию, микроструктуру продуктов после синтеза и продуктов после термической обработки при высокой температуре (1100 градусов по Цельсию). Определить концентрацию химических элементов и изучить термическую стабильность биокерамики гидроксиапатита и биокерамики $\mathrm{Mg}$-замещенного гидроксиапатита. Мg-замещенный гидроксиапатит с переменным количеством $\mathrm{Mg}(0.21-4.72$ мас\%), интегрированным в структуру, был синтезирован путем мокрого химического осаждения из $\mathrm{CaO}, \mathrm{MgO}$ и $\mathrm{H}_{3} \mathrm{PO}_{4}$. Рентгеновский дифракционный анализ не показывает наличие $\mathrm{Mg}(\mathrm{OH})_{2}$ и $\mathrm{MgO}$ в $\mathrm{Mg}$ замещенных продуках после синтеза и термообработки, это указывает на полное включение $\mathrm{Mg}$ в структуру гидроксиапатита. Данные сканирующей электронной микроскопии/энергии дисперсионной рентгеновской спектроскопии указывают на то, что концентрация $\mathrm{Mg}$ в $\mathrm{Mg}$-замещенном гидроксиапатите растет за счет увеличения содержания $\mathrm{MgO}$ в исходном $\left(\mathrm{Ca}(\mathrm{OH})_{2} / \mathrm{Mg}(\mathrm{OH})_{2}\right)$ растворе. Термическая стабильность $\mathrm{Mg}$-замещенного гидроксиапатита уменьшается за счет увеличения количества Мg в продуктах, происходит частичное преобразование $\mathrm{Mg}$-замещенного гидроксиапатита в $\mathrm{Mg}$-замещенный $\beta$-трикальцийфосфат. Включение Мg в структуру гидроксиапатита существенно влияет на морфологию и микроструктуру. Для гидроксиапатита характерна морфология агломератов игольчатых кристаллитов, тогда как для Mg-замещенного гидроксиапатита - морфология агломератов пластинчатых кристаллитов. 